\title{
A.JO'「巨
}

African Journal of Teacher Education

ISSN 1916-7822. A Journal of Spread Corporation

Vol. $82019 \quad$ pp. 159-193

\section{Employee Voice Contexts and Teacher Retention in Remote Secondary Schools in Tanzania}

\author{
Raymond Mwemezi Boniface \\ Department of Educational Foundations, Management and Lifelong-Learning, \\ University of Dar es Salaam, Tanzania.
}

\begin{abstract}
Retaining teachers in their work stations is influenced by many factors which are contextually explained. Teachers' retention practices in Tanzania and most Sub-Saharan African (SSA) countries have been ineffective partly because of being monetary based. While 'voicing' is regarded as a more feasible strategy for retaining teachers in these countries, conditions which favour voicing over exiting a remote school particularly in the Tanzanian context have been not systematically mapped out. This article presents and discusses seven conditions, to include: empowering, listening and cooperative leadership; habitability; friendliness outside school environment; investment potentialities; a supportive and peaceful school working environment; life as a "challenge" mindset; as well as patriotism and profession commitment, which were found to favour voicing over exiting a remote school. The findings imply that there is a need to empower teachers to influence change and reforms that matter to them, increasing teachers sense of investment in schools they are posted and in the profession (social and financial capital), checking 'who goes into the teaching profession and with what level of struggle'; improving school-level relationships including justice practices from leaders and management, positive coworkers exchanges; training teachers to become patriotic to the nation and be committed to the teaching profession; and the need to improve cooperation and understanding between schools and their surrounding communities.
\end{abstract}

Key words: exiting, remote school, school level strategies, Tanzania, teachers' retention, voicing. 


\section{Introduction}

Teachers' retention forms an important aspect in teaching resource planning and management practices. Entire employee planning efforts, including training, are totally meaningless if such employees cannot be properly retained. Evidence shows that teachers' retention is a critical problem in Tanzania as it is in many other parts of the world, mostly affecting remote areas (ITFTEFA, 2010; Moon, 2007; URT, 2008). For example, it is documented in the Tanzanian Teachers' Development and Management Strategy (TDMS) that

...there is an acute shortage of teachers at all levels and in almost all subjects, including the subjects of the biased curriculum. More specifically the situation is worse for science, mathematics and language subjects. Remote and peripheral areas critically suffer from shortage of teachers...the teaching and learning environment is not motivating, making it difficult to attract, obtain, train, and retain high quality teachers in schools. This situation needs immediate attention ... (URT, 2008, pp. 9, 10.)

While teachers' retention is a critical problem, most countries, including Tanzania, have consistently been unable to come up with strategies for their retention particularly in remote areas. This is because retaining a teacher is a function of many combined factors. The few observable strategies to attract teachers in remote areas in Tanzania (URT, 2008) and other African countries have been strongly criticized as being hardly implementable (January, 2010; Chenelo, 2011; Mbiling'i, 2011) as they are monetary based (Mulkeen, David, Joan \& Elizabeth, 2007; URT, 2012). There is, therefore, a need to investigate less monetary inclined teachers' retention alternatives. One of these strategies is to inquire into different ways under which teachers could be empowered to voice, and therefore remain in remote schools, instead of exiting.

A dissatisfied teacher in a remote school has two options at his /her disposal. The first option is to 'voice' and the second one is to 'exit'. 'Voice' is used to mean the possibility of a teacher to remain and search (in different ways) for solutions to his/her dissatisfaction in a remote school, while 'Exit' means leaving a remote school (Armstrong, 2006; Gorden, 1988; Hirschman, 1970; McCabe \& David, 1992). Employee voice, therefore, covers a whole variety of processes and structures which enable and sometimes empower them, directly or indirectly, to contribute to decision-making in the firm (Boxall \& Purcell, 2003). It is 'the ability of employees to influence the actions of the employer' (Millward, Alex \& John, 2000). The concept covers the provision of 
opportunities for employees to register discontent and modify the power of management. It embraces involvement, and more significantly, participation. Several ways that employees could voice their dissatisfactions have been documented around the world. These include formal grievance procedures, suggestion systems, arbitration, mediation, employee-management meetings, counselling service, ombudsman, non-management task forces, question and answer programmes, and survey feedback (Armstrong, 2006; McCabe \& David, 1992; Spencer, 1986). This could be done individually, i.e., bringing desired changes, or collectively, that is, contributing to the desired changes (Dowding, John, Mergoupis \& Van Vugt, 2000). Moreover, both individual and collective voicing can be done directly-through two-way communication with another member of the organization (for instance when an individual discusses a problem with a supervisor or team member), or indirectly through representatives (Luchak, 2003).

Employee voicing and exiting are therefore meaningfully connected to retention and attrition. While voicing and exiting seem to offer viable strategies to teacher retention, this area has not attracted significant attention in teachers' retention efforts, especially in the Tanzanian context. This study inquires into this issue using experienced teachers to get relevant contexts which are considered facilitative of voicing over exiting a remote school. Experienced teachers in this context are those who have worked and lived in remote schools for not less than six months. $84.9 \%$ of teachers involved in this study had lived and worked in remote rural areas in between one and ten years (Boniface, 2016).

\section{Aim of the Study}

The aim of this study is to establish conditions under which a teacher could decide to voice instead of exiting a remote school. It was guided by two research questions: The first question was: Under what "perceived school level conditions" can a teacher voice his/her concerns instead of exiting in a remote school? The second question was concerned about what the implications of these perceived conditions on retaining remote teachers are.

\section{Literature Review}

\section{Why Teacher Retention?}

Teacher retention, for quite some time now, has been a topic of critical focus among academics, researchers, practitioners and policymakers (Guarino, Santibañez, Daley \& Brewer, 2004; 
Ingersoll, 2001; Johnson \& Birkeland, 2003; National Commission on Teaching and America's Future, 2003). The core question has been why teachers leave or remain in the teaching career. Researchers in this area have therefore continuously sought to find answers to that question so as to be able to successfully retain teachers, especially 'quality teachers'. This is because research has confirmed that teacher quality makes a difference in student learning (Akiba, Gerald \& Jay, 2007; Goldhaber \& Anthony, 2004; Rivkin, Hanushek \& Kain, 2005; Rockoff, 2003; Rowan, Correnti \& Miller, 2002; Rowe, 2003; Sanders \& Horn, 1998; Sanders \& Rivers, 1996; Stronge, et al., 2007; Sumra, 2004; Wright, Horn \& Sanders, 1997). For instance, Coleman, Campbell, Hobson, McPartland, Mood, Weinfeld and York (1966) concluded that teacher characteristics tend to explain more variance in student achievement than any other school resource. Rowe (2003) as well as Sanders and Horn (1998) document that the teacher may be the "most important factor in the academic growth of students." Pitsoe and Pertunia (2012), and Ntim (2013) indicate that teachers are not only placed at the centre of students' success, but also at the heart of education quality and students' learning outcome debates. Within the fast and frequently changing world to date, few will disagree on the critical role of teachers in preparing young people to face the future with confidence, build it with purpose and become responsible global citizens. This is because teachers are the key facilitators of the teaching and learning process, and core implementers of educational plans and programmes (Ntim, 2013).

Unfortunately, however, despite researchers' tireless efforts, to effectively attract and retain quality teachers remains a baffling puzzle (Moon, 2007). In Tanzania, there is plain evidence that teachers assigned in remote rural schools report in low numbers, and even those who are already there seek transfer to urban areas (Tanzania Education Sector Analysis-TESA, 2011; URT, 2008). Significant evidence has shown that, despite high-turnover schools serving large populations of low-performing and low-income students who are in greater need of consistent and supportive school experience (Boyd, Pam, Marsha, Ing., Hamilton, Susanna \& James, 2011), these schools are mostly found to be exposed to inconsistent staffing from year to year, while students are taught by an increasing number of inexperienced teachers (Rivkin, Hanushek \& Kain, 2005). Within that context, some questions are worth asking: Can 'equality of educational opportunity' of staffing every classroom in remote schools with a highly qualified and talented teacher (Borman \& Maritza, 2008) be attained? How can global educational reforms and restructuring be realized? In the Tanzanian context, for instance, where many students are enrolled in poor schools in remote 
rural areas, teacher attrition is likely to create social and educational injustice and stratification, hindering learners from nourishing their valued capabilities acquirable from quality education and equality in educational opportunities (Tikly \& Barrett, 2010, 2011).

\section{Challenges of Retaining Teachers in Remote Contexts.}

Some notable challenges that are encountered when it comes to retaining teachers in remote areas are those of their demographic characteristics: of gender (Borman \& Maritza, 2008; Griffeth, Hom \& Gaertner, 2000; Stockard \& Michael, 2004), age and years in the profession (Ahuja, Chudoba, Kacmar, McKnight \& George, 2007; Armstrong, 2014; Borman \& Maritza, 2008; Griffeth et al., 2000; Kavanaugh, Jo \& Juliana, 2006; Wilson, Squires, Widger, Cranley \& Tourangeau, 2008; Stockard \& Michael, 2004), marital status ( Griffeth et al., 2000), qualification / education level (Agyeman \& Ponniah, 2014; Borman \& Maritza, 2008). While teachers' demographics could be a challenge to retaining teachers across many contexts, it is likely to be even more challenging for remote areas with an unsatisfactory environment. Additionally, male teachers who are most likely to stay and are normally found in remote schools, are noted in previous research to be rarely satisfied with their teaching career.

Moreover, previous research pinpoints the uneven distribution of teachers across areas (Akyeampong \& Lewin, 2002; Lewin, 2008; Mulkeen, 2010; UIS, 2006). Remote areas are strongly affected, with fewer, mostly unqualified, teachers. The imbalance is so strong that it is possible to find unemployed qualified teachers in urban areas while there are unfilled vacancies in remote ones. This is exacerbated by the wastage phenomena and by the availability of possibly well-paying alternative employments in urban areas (Mulkeen, 2010; Mulkeen et al., 2007). More generally, other challenges to retaining teachers include the increasing roles assigned to poorly prepared school heads, which makes school management weak (Dadey \& Harber, 1991; De Grauwe, 2001; Gottelmann-Duret \& Hogan, 1998; Kucera \& Stauffer, 2003; Mulkeen, 2010; Riley, 1999; Ross \& Hutchings, 2003;UNESCO, 1996), the increasing difficulty of retaining female teachers due to local community practices and personal factors ((Bennell \& Akyeampong, 2007; Bernard, 2002; Kadzamira, 2006; Lowe, 2006; Mulkeen \& Chen, 2008), the diversity in local languages in remote areas affecting teachers' effectiveness in supporting teaching, learning, and integration into the community (Bennell, Hyde \& Swainson, 2002; Brock-Utne, 2007; Mulkeen, 2010), the effect of the HIV/AIDS pandemic (Mulkeen, 2010; Mulkeen et al., 2007; 
Kelly, 2000; Pitsoe, 2013), and poor practices in teachers' promotion and advancement (Gaynor, 1998; Mkumbo, 2012; Mulkeen, 2010; Mulkeen et al., 2007; VSO, 2002). In addition, it seems more challenging to retain teachers with low intrinsic motivation for the career coupled with a low sense of career investment in remote areas (Borman \& Maritza, 2008; Kirby \& Grissmer, 1993; Leung, 2008; Mkumbo, 2012; Mulkeen et al., 2007; Ntim, 2013; Ramlall, 2004; Shen, 1997; Towse, Kent, O-saki \& Kirua, 2002; Tye \& O’Brien, 2002).

\section{Feasibility of Teachers Retention Strategies in Remote Contexts: A Critical View}

The efficacy of a few observable strategies to attract teachers in remote areas in Tanzania such as introducing reward systems, fee exemptions for students' teachers, and increasing attractive incentive packages (URT, 2008) is questionable. Most of these policies are financially or economically based, minimal, unsatisfactory, and ineffective (Chenelo, 2011; January, 2010; Mbiling'i, 2011). Research evidence indicates that monetary-related policies and incentives are difficult to implement in retaining teachers in countries like Tanzania, where such a resource is scarce (Mulkeen et al., 2007; URT, 2012). In Tanzania, the difficulty is evidenced, for instance, in the continuous strikes and confrontations at different times between the teachers' union and the government over the issue of salary and fringe benefits for teachers (Onyango, 2013; Peter, 2012; Rweyemamu, 2013, 2014; Yankami, 2014).

Moreover, policies addressing the shortage of teachers in Tanzania seem to focus more on supply-side solutions, especially enrolment expansion, while paying less attention to the demand side, particularly the 'revolving door' whereby teachers, for various reasons, leave the teaching profession in unprecedented numbers. Hence, though many teachers are being trained, yet, they cannot be traced in the education system. Thus, getting more teachers into the career pipeline alone cannot address teachers' deficit problem (Pitsoe \& Pertunia, 2012). Evidence shows that many teachers immediately after graduation have continued to flee from the teaching profession, instead of going to classroom (Onyango, 2013; Peter, 2012; Rweyemamu, 2013, 2014; URT, 2008; Yankami, 2014). Suggestions such as forcing teacher graduates into classes without proper motivation are even worse. It is likely to generate a negative outcome in practice and in effect. The other teacher retention policy option considered has been to recruit and/or post teachers from within their local areas of origin. However, evidence indicates that the policy is hardly attainable, 
as most teachers usually do not want to be posted to their home areas due to the burden of extended family obligations (Bennell \& Mukyanuzi, 2005).

\section{Complexities in Teachers Retention}

While teachers' retention is a critical problem, most countries, including Tanzania, have consistently been unable to come up with feasible strategies for their retention. One possible explanation could be the complexities involved in researching teachers' retention and attrition. Scholars of this topic have adopted two major approaches, the first being a multivariate or theoretical approach, and the second being a bivariate approach.

The first, the multivariate or theoretical, approach inquiries into a set of variables simultaneously to test theories of explaining why teachers choose to stay in or leave the teaching profession (Shen, 1997). Some of these theories include: career choice theories such as the Work Adjustment theory; Holland's Vocational Personalities in Work Environment; Super's Selfconcept Theory of Career Development; the Social Cognitive Career Theory; and Gottfredson's theory of Circumscription and Compromise (Leung, 2008). They further include motivational theories such as Need theories - Maslow's Need Hierarchy and McClelland's Need theories; Equity theory; Expectancy theories - Vroom's Original Theory and Porter and Lawler's Extension Theory; as well as a job design model - Herzberg's Motivator-Hygiene Theory and Job Characteristics Model (Ramlall, 2004). Other theories include Human Capital theory (Kirby \& Grissmer, 1993; Shen, 1997) and the theory of teachers as economically rational decision makers (Shen, 1997).

The second approach, the bivariate approach, inquires into the relationship between retention/attrition and another variable (Shen, 1997). For example, Borman and Maritza (2008) in their comprehensive meta-analysis study document that teacher attrition and retention can be related to teachers' demographic characteristics (gender, teacher race, age, marital status, having/not having a child, number of children); teachers' qualifications (teacher training, experience, teacher ability or achievement, teaching specialty area); school resources (average class size, teacher-student ratio, school expenditure for support per teacher, school expenditure for teaching materials, teacher classroom assistance, instructional spending, per pupil spending, salary); school organizational characteristics (school location, sector, size, administrative support, beginners' mentoring programmes, collaboration \& teachers' network, regular supportive 
communication with administrators, opportunities for advancement, bureaucracy; and school student body characteristics (students' achievement levels, the school socioeconomic composition, racial/ethnic school composition).

This clearly shows that studying teachers' retention (and attrition) can be examined (as has been done) from many angles, with different approaches, depending on specific study interests. This paper discusses teachers' retention from the organizational perspective (organizational support), and therefore, adopts Organizational support theory (OST) which offers an understanding on voicing and exiting phenomena.

\section{Theoretical Stance}

This study draws from the Organizational Support Theory (OST) and its central construct, Perceived Organizational Support (POS): "the degree to which employees believe their work organization values their contributions and cares about their well-being (Eisenberger Huntington, Hutchison \& Sowa, 1986; Rhoades \& Eisenberger, 2002).” Within organizations, some employees have vested interest in authorities or rights over other employees on the basis of their knowledge, experience, skills or any other bases. These appointed authorities are considered agents of the organization, and their actions are considered organization actions. This is because employees relate to their organization as a person because they have been constituted into the legal fiction of a person and its acts are considered to be the acts of human beings (Eisenberger et al., 1986; Levinson, 1965). Organizations, therefore, have a relational agency with all its employees. Implicitly, support of any kind from employees is translated as support from the organization. Such a broader perception of organization has necessitated examining its support from several angles. Key categorizations of POS are notable in Woo (2009) and in Chou and Robert (2008). In their studies, it is argued that POS could be studied from three main perspectives: support from management, from supervisors /leaders, and from co-workers /colleagues/peers. Hence, organizational support broadly means support from these three categories or perspectives. In alignment with OST/POS, the study further incorporates two models related to the analysis of exchange that exists in organizations. These are 'Leader - Member Exchange (LMX) and 'Coworkers" Exchange (CWX). 


\section{Leader-Member Exchange (LMX):}

This is sometimes referred to as "the relationship-based approach to leadership" (Schriesheim, Stephanie \& Claudia, 1999). LMX has its roots in the Social Exchange Theory (Blau, 1964) and assumes that relationships of varying quality develop between leaders (or supervisors) and different subordinates in working places (DeConinck, 2009; Erdogan \& Jeanne, 2007; Gerstner \& Day, 1997; Schriesheim, Stephanie \& Claudia, 1999). It is presumed that the quality of the relationship that develops between a leader and a follower is predictive of outcomes (attitudes and behaviour) at the individual, group, and organizational levels of analysis (Gerstner \& Day, 1997; Liden, Sparrowe \& Wayne, 1997).

Co-worker's Exchange (CWX):

Co-workers have been noted as central to workgroup culture and form a distinguished basis for organizational commitment and social support (Leah \& Colin, 2013). CWXs describe the dyadic relationship shared by two peers who report to the same manager (Sherony \& Green, 2002). Coworkers form varying exchange relationships among themselves, characterized by different levels of trust, respect and loyalty (Leah \& Colin, 2013; Sherony \& Green, 2002). Co-workers are important as they define the social environment, serve as organizational guides (clarifying role ambiguity, mitigating conflicts and ameliorating overload), help to reduce peer turnover intentions and may be able to satisfy interpersonal and professional needs far beyond what LMX can do (Basford \& Offermann, 2012; Chiaburu \& Harrison, 2008; Clay \& Olitt, 2012; Siegal, 2000).

\section{LMXs, CWXs and group dynamics:}

Evidence suggests that high-quality leader-member relations act as (affective and calculative) forces that embed staff in the organization, influencing their retention (Ballinger, David \& Schoorman, 2010). The latter forces, affective and calculative, respectively relate to benefits accrued by in-group members from positive LMX like trust or better communication with a leader, and the perceived high utility related to alternative receivable from tangible benefits like protection, job latitudes, and extra resources to perform critical tasks by in-group members (Ballinger, David \& Schoorman, 2010).

Moreover, organizational support, in its broadest sense, is widely acknowledged as an influence on turnover and retention (Ballinger, David \& Schoorman, 2010; Gerstner \& Day, 1997; 
Leah \& Colin, 2013; Liden et al., 1997). More intriguing is the evidence that, even in the absence of tangible benefits, high-quality relationships (reflected in understanding and friendship or intangible benefits) are valuable for being related to employee well-being (Epitropaki \& Martin, 1999, 2005). Good organizational relationships and support would, arguably, embrace employee voicing and, in return, mitigate exit. Armstrong (2014) writes, “...the level of job satisfaction is affected by...the quality of supervision, social relationships with the workgroup and the degree to which individuals succeed or fail in their work (p. 264)".

\section{Research Design and Methodology}

The study was conducted in Dodoma region within three districts of Chemba, Kondoa and Mpwapwa. Dodoma region and the three chosen districts display serious hardships in terms of the working and living environment for teachers. For example, a review of the 2013 government education reports for the Dodoma region indicates shortages in important infrastructure and furniture, comprising of classrooms, teachers' housing, latrines, administration blocks, laboratory, stores, hostels, students' tables and desks, cupboards, teachers' chairs and tables, shelves and beds (SEDP Report, URT, Dodoma, 2013). Moreover, there is a significant shortage of teachers and the region has quite a long-standing record of not achieving satisfactory results in national examinations (Mkumbo, 2012). Schools with an even larger shortage of teachers, teaching, and learning facilities, as well as relatively poor academic records and located far (at least $30 \mathrm{~km}$ ) from district municipalities were specifically chosen.

A sample included 28 schools (5 used in the pilot, and 23 in surveys and follow-up interviews), 27 school heads (4 used in the pilot study, and 23 in surveys and follow - up interviews), and 231 teachers [61 used in the pilot, and 170 in surveys and follow - up interviews). Schools and school heads who were used in the pilot were purposively sampled whereby school heads (used in surveys and follow - up interviews) and all teachers were simple randomly sampled.

Data were sequentially collected in three phases (as suggested by Creswell, 2003; 2009): by a pilot study, surveys and follow-up interviews. Qualitative data were first collected in Kondoa district in a pilot study. The results informed the construction of the survey questionnaire, which was then used to collect quantitative data in Dodoma's three districts of Kondoa, Chemba and Mpwapwa. Then, qualitative data were collected as a follow up of the survey results with 
interviews in selected schools in Mpwapwa district. Data were collected using a survey questionnaire and interviews.

The analytical procedures followed included data transformation, i.e., quantitizing (converting qualitative data into quantitative data) and/or qualitizing (converting quantitative data into qualitative data) (cf. Caracelli \&Jenniffer, 1993; Driscoll, Appiah-Yeboah, Salib \& Rupert, 2007; Johnson \& Larry, 2012; Tashakkori\& Teddlie, 1998; Teddlie \&Stringfield, 1993). While quantitizing helped to see the apparent weight of each theme in the dataset, qualitizing simplified narrative descriptions of data from numerical perspectives. Braun and Clarke's (2006) thematic analysis techniques and procedures were followed to generate themes and sub-themes from the interview data. Close-ended questions from surveys were subjected to descriptive statistics with the support of IMB SPSS (Statistical Package for the Social Sciences) data analysis assisting software to generate frequency distributions (tables).

\section{Findings}

As highlighted earlier on in this paper, the study aimed at establishing conditions under which a teacher could decide to voice instead of exiting a remote school. The findings are summarized in.

Table 1

Conditions for teachers' voicing in a remote school

\begin{tabular}{|c|c|c|c|c|c|}
\hline \multirow[t]{3}{*}{$\mathrm{S} / \mathrm{N}$} & \multicolumn{5}{|c|}{ Influential "perceived voicing" contexts } \\
\hline & \multirow[b]{2}{*}{ Contexts/Condition(s) } & \multicolumn{3}{|c|}{ Qualitized survey results } & \multirow{2}{*}{ 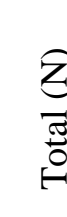 } \\
\hline & & $\begin{array}{l}\text { Agreeing } \\
\text { Group (N/\%) }\end{array}$ & $\begin{array}{l}\text { Disagreeing } \\
\text { Group (N/\%) }\end{array}$ & $\begin{array}{l}\text { Not sure } \\
(\mathrm{N} / \%)\end{array}$ & \\
\hline 1. & $\begin{array}{l}\text { Empowering, listening and } \\
\text { cooperative leadership }{ }^{1}\end{array}$ & $119(73.5 \%)$ & $30(18.5 \%)$ & $13(8 \%)$ & 162 \\
\hline 2. & Habitability $^{2}$ & $116(71.6 \%)$ & $14(8.7 \%)$ & $31(19.1 \%)$ & 161 \\
\hline
\end{tabular}

\footnotetext{
${ }^{1}$ Supportive in solving teachers' problems, involving teachers in decision-making.

${ }^{2}$ A habitable environment mainly prioritizes the presence of decent teachers' houses and other important human services such as clean and safe water, electricity and healthy centres.
} 


\begin{tabular}{|c|c|c|c|c|c|}
\hline 3. & $\begin{array}{l}\text { Friendliness outside of the } \\
\text { school environment }^{3}\end{array}$ & $105(64.9 \%)$ & $26(16 \%)$ & $29(17.9 \%)$ & 160 \\
\hline 4. & Investment potentialities & $103(63.6 \%)$ & $36(22.3 \%)$ & $22(13.6 \%)$ & 161 \\
\hline 5. & $\begin{array}{l}\text { Supportive and peaceful } \\
\text { school } \\
\text { environment }^{4}\end{array}$ & $99(61 \%)$ & $24(14.5 \%)$ & $39(24 \%)$ & 161 \\
\hline 6. & $\begin{array}{l}\text { Life as a "challenge" } \\
\text { mindset }\end{array}$ & $93(57.4 \%)$ & $39(24.1 \%)$ & $29(17.9 \%)$ & 161 \\
\hline 7. & $\begin{array}{l}\text { Patriotism \& Professional } \\
\text { commitment }\end{array}$ & $77(47.5 \%)$ & $41(25.3 \%)$ & $41(25.3 \%)$ & 159 \\
\hline \multicolumn{6}{|c|}{ Non-influential "perceived voicing" contexts } \\
\hline 1. & Locality (Nativism) policies & $55(33.9 \%)$ & $65(40.1 \%)$ & $39(24.1 \%)$ & 159 \\
\hline 2. & No "alternative door" beliefs & $25(15.4 \%)$ & $65(58.6 \%)$ & $36(22.2 \%)$ & 156 \\
\hline
\end{tabular}

The conditions found in the data were grouped into two broad categories. First, influential and, secondly, non-influential "perceived voicing" contexts. The first category contains seven conditions under which teachers' responses from the "agreeing group" were higher than those of the "disagreeing group". Implicitly, these are conditions under which the majority of teachers favour voicing before exiting a remote school. They are labeled "influential perceived voicing contexts". In the second category, two conditions were found where responses from the "disagreeing group" were higher than those from the "agreeing group". They are labeled "noninfluential perceived voicing contexts", implying that the majority of teachers would not favour voicing over exiting under those conditions. In the paragraphs that follow the conditions are presented with the support of verbatim quotations.

\footnotetext{
${ }^{3}$ Respect, recognition, valuing and support from the community surrounding the school, particularly parents. ${ }^{4}$ Coworkers' support, conflicts/grievances resolution frame, palatable teaching and learning facilities coupled with students' discipline.
} 


\section{Influential "perceived voicing" contexts}

\section{Empowering, listening and cooperative leadership}

Teachers' empowerment at the school level is described as one of the important aspects of positively influencing teachers' intention to stay instead of leaving a remote school. Empowerment is identified alongside 'attentive and cooperative leadership'. Most of the teachers (73.5\%) who responded to this question supported this condition. Only $18.5 \%$ disagreed, while $8 \%$ were not sure. Empowering especially entails giving classroom teachers voice to influence classroom activities and broad school level decisions. This means that teachers are given 'real autonomy' on various issues at the school level. When coupled with a leadership which is supportive and cares about teachers' concerns, it is possible to find that teachers could opt to remain rather than leave.

One of the critical factors which the study identifies as leading teachers to leave is the inability to contribute to their school development because of school leadership practices. Notably, a number of teachers single out school leadership as being an important source of teachers' dissatisfaction at the school level. One of the teachers commented:

...many teachers have good and excellent ideas, but they are segregated...mmhh...not listened to at all... and this is highly discouraging and demoralizing.... Dictatorship kind of leadership...not advisable. Whenever a teacher provides advice, he/she is seen as an enemy and enmity starts. In such situation, teachers develop inferiority complex and cannot provide their ideas or advice or suggestions... you find the school head initiating unnecessary conflicts with any teacher providing opposing or critical ideas to the management... a teacher becomes unfree, uncomfortable and decides to leave.

\section{Habitability}

Is the area habitable for humans? Teachers emphasize the presence of at least a minimum of social services, and especially teachers' housing, clean and safe water, and electricity are matters which could make them think of staying. While solving teachers' housing and other social problems might not be an easy task at the school level, several suggestions of how to look at it were advanced. One teacher suggested:

...if they cannot build them, then at least they should look for them within the school surrounding environment and assist in paying rent for teachers... 
Another teacher suggested:

School management in collaboration with the village government where the school is located needs to see the importance of building teachers' houses around the school or near school premises. This will help in terms of managing teachers and supporting them in case of immediate problems.

\section{Friendliness outside the school environment}

Teachers describe the predominant model of living in remote rural areas as being communalist. People are highly dependent on social support within their environment for conducting different activities. Schools are built within communities, and teachers emphasize that they need strong support from those communities, especially parents' support. One reason identified as to why teachers are unwelcome and disrespected is the low value attached to education and cultural practices in remote areas. One teacher clearly noted:

I am not sure in other areas, but here in this region, a teacher is seen as an invader, without home origin, a fool. People are very disrespectful and look down upon teachers. What they are interested in is marrying and getting married. For instance, a teacher who is unmarried is highly disrespected such that many teachers see it better to leave...I have also noticed many cases of parents convincing and telling their children to devalue teachers and the teaching profession.

It was also reported that some parents in remote areas use children as their sources of income. A teacher noted,

... some parents tend to send their girl children to unmarried male teachers' houses with the pretence to help with home chores... A girl would stay in the house until late hours in the evening/night. Parents then ambush the house claiming the teacher has sexually abused the girl, forcing him to give some money or else they would report the incidence to the police or the school where the teacher is teaching or to the teachers' union. In fear of damaging their reputation and integrity, the teacher ends up agreeing with the parent's demands.

Issues of robbery and witchcraft also surfaced in one teacher's responses: 
...there is a bad ideology among people in remote rural areas...they think teachers have a lot of money, so we sometimes get robbed ... many teachers are complaining of witchcraft. ... they are made as trial objects by wizards... . This especially makes teachers run away from these remote schools.

\section{Investment potentialities}

Most teachers (63.6\%) describe the availability of opportunities for increasing their incomes as indeed being influential in their decision to stay in remote areas. While this is probably a problem for all teachers in the country, those in the urban centres are seen to have more opportunities for topping up their incomes, such as giving extra private teaching for payment, popularly known as "tuitions". This is because the social and economic standards in urban areas are higher compared to remote rural areas. One teacher commented:

... we have complained for a long time... what we earn is very little, not enough at all...I have family and relative to support, but I cannot and I feel really bad....may be the school management can see how we can make extra money here in our environment...that is important to keep us going...

\section{Supportive and peaceful school working environment}

Teachers are particularly concerned about collegial support and harmony at the school level. It also includes a working environment where there is no conflict. Further, teaching and learning facilities, as well as students' discipline, were noted to be critical.

One of the issues noted in a remote school which could help in building a peaceful working environment is an organ for resolving conflicts. It seems as if teachers have no specific and reliable mechanism of expressing and solving their problems and conflicts at the school level, as one of the teachers indicated:

...we teachers here have many problems. But, where do we express them? There is no conflict or say dissatisfaction resolutions systems in schools. This means that teachers have no special and reliable place to reveal their frustrations...we all suffer internally... and I would say that this is indeed a big problem in many schools...

\section{Life as a "challenge" mindset}


It was found that contemporary teachers start their work with the 'life is easy' mentality. This is typically a mindset developed while still in college and in the university environment; it was the life they lived while studying. However, the working arena for teachers in countries like Tanzania cannot be expected to be very easy. The concern was raised by respondents (teachers) that student teachers in universities and teachers training colleges ought to be given a special course on how to develop an appropriate mindset in line with the practical teaching environment in the country. Most teachers (57.4\%) who responded to this aspect show their endless concern about the critical importance of building up in teacher trainees' minds that life is about challenges. On this issue, one teacher commented:

Teachers we get today seem unaware of the real teaching environment in the country. Most schools are in remote rural areas. By the time student teachers decide to join the teaching profession should be aware of that...they think the working environment is easy, no, it is not...I think they are misled by expecting a continuation of the kind of life they live[d] while studying... universities and colleges must help us on this.

\section{Patriotism and profession commitment}

Majority of the respondents (47.5\%) supported the need for teachers to be patriotic to their country and to be committed to the teaching profession, while $23.5 \%$ did not, and $25.3 \%$ were not sure. The findings suggest that teachers should be taught to feel proud of teaching anywhere in the country without being much bothered by school level conditions given that they are 'educating their nation.' Moreover, teachers should be taught to be committed to the teaching profession. While the study did not investigate whether teachers are committed or not to their profession, data suggest that the retention difficulties noted are partly explained by teachers' lack of loyalty to the teaching profession. One school head observed:

I think many people who go into the teaching career are not really interested in teaching...they are not there to make sure the profession grow...I think the nationalism spirit is also an issue... 


\section{Non-influential "perceived voicing" contexts}

\section{Locality (Nativism) policies}

In the pilot study, it was perceived that posting teachers to remote schools located in areas where they come from would increase their retention. This is labeled "locality retention policies." The logic is that posting teachers to remote areas where they do not originate makes their lives miserable leading them to quit. Therefore, the assumption was that it should be easy for teachers who originate from those areas, who are already used to the environment and have relatives and friends, to find it easy to stay. However, the survey data indicate that $40.1 \%$ disagreed that such policies could lead to teachers' voice in favour of exit in remote contexts, while $33.9 \%$ think that the policy could work, and $24.1 \%$ were not sure. One of the comments on this issue was as follows:

...I am not quite sure if sending teachers into areas they come from is a solution to make them stay. I think it is important to address teachers' problems...teachers should be able to work anywhere in the country...

\section{No "alternative door" beliefs}

The other condition which initially was considered may possibly lead to voice over exit is the lack of alternative jobs. This hinges on the belief that teachers who leave remote schools probably find employment somewhere else. It was initially noted from the pilot study that teachers could choose to stay rather than leave if there was no other job for them to join. However, the survey data indicates that $58.6 \%$ disagreed, while only $15.4 \%$ agreed and $22.2 \%$ were not sure. The data suggest that it is technically wrong to assume that teachers will stay in a remote context simply because they cannot get another job without addressing critical low retention causes. It is also important to note that a significant number of respondents were not sure whether the lack of alternative jobs could influence them to stay or not. This could mean that some teachers are likely to stay in a remote condition for some time, while a small change, either in improved school level support or finding slightly better opportunities could affect whether or not they were retained or swept away. One teacher commented on this:

...some teachers have left here because of poor environment. I have information others have not got another job yet... sometimes staying here is equally as being unemployed...it really makes little or no difference... 


\section{Discussion}

Looking at influential 'perceived voicing' contexts, the findings from this study suggest that to opt for voicing over exit, teachers in remote schools value opportunities that could positively and effectively allow them to participate in and contribute towards a meaningful change in building a satisfactory school working environment. This is built into the belief that changes are possible, which perceives the voice option as a promising tool towards a successful end. The findings echo other studies in the area of voicing and exiting (Hirschman, 1970; Rusbult, Johnson \& Morrow, 1986; Withey \& William, 1989) arguing that choosing voicing over exiting for teachers is an option likely to be strengthened by the extent to which teachers feel that they have invested in their profession and in the schools they are working in, including their social capital and entry costs (barriers). Those with a high investment in the profession or schools [for instance possessing a high social capital, having struggled dearly to join the profession, possessing a specific professional knowledge, or having other investments like businesses (depending on school contexts)] are likely to opt for voice because of the high exit cost. Moreover, the findings partially echo the argument by Rusbult et al (1986) that choosing voicing over exit could be more plausible to the extent that teachers' movement elsewhere is made 'easy and possible' due to the presence of other quality alternatives within the labour market. Yet, in contrast to Rusbult et al., (1986), the current study shows that teachers in remote contexts might opt to exit regardless of the presence of alternatives, depending on the extent with which they are dissatisfied. Within that context, it could be argued that, regardless of opportunities that could be intentionally created in the rural or remote areas to give voice to the employee, remoteness and rurality generally have an unwelcoming and, especially in Africa, poorer life quality reality. Teachers therefore want to leave for the city even when their economic lot is not better there.

Looking at Non-influential 'perceived voicing' contexts, observations from 'locality (nativism) policies' show that although it seems logical to think that recruiting and positing teachers from areas of their origin could strengthen voicing, yet, such an outlook need to be taken with care. Consistent with Bennell and Mukyanuzi (2005), the economic costs of voicing become higher for natives because of the burden of extended families. In contexts where there are many de-motivators in remote schools, including low salaries and meagre investment opportunities, the exit cost may be deemed low as compared to voicing for native teachers. Notably, observations from 'locality (nativism) policies' align with 'no alternative door beliefs' to show that teachers 
might decide to quit even if they are not sure of alternative employment. Such observations are in some sense in contrast with a number of studies (Rusbult et al., 1986; Withey \& William., 1989) which observed that the exit option was greatly associated with the presence of better-quality alternatives.

While it is obvious that teachers who quit remote schools go elsewhere, yet, the current study does not suggest that teachers will stay because they do not have other alternatives. This is evident in teachers' views that sometimes staying and working in remote contexts may be equated to having no job (or being jobless), as it makes no significant difference between them and other unemployed persons in the urban street. The findings signify that teachers may exit when the environment becomes extremely dissatisfying even in the absence of feasible alternatives.

In terms of theory, the findings show that the concept of leader-member exchange (LMX), co-worker exchanges (CWX) and organizational support theory/perceived organizational support (OST/POS) offer meaningful insights into extending the understanding of how and why empowerment, listening and cooperative leadership are essential to facilitate meaningful voicing practices. This is because cooperation is enhanced through an ability to collaborate especially within strengthened collegial relations. This is clearly notable where there is collective help, assistance, sharing, and work (Little, 1990). However, a smooth cooperative school atmosphere is possible within supportive school heads' contexts -that is, a school head who is 'listeners' and teachers' empowering'. Such supportive contexts would reflect quality exchanges between school heads and classroom teachers (i.e. LMXs) and classroom teachers themselves (i.e. CWXs). The findings draw significant implications for school-level leadership and management practices, including enhancing teachers' perceived sense of robust 'investment" opportunity that is capable of influencing voice and retention thereafter in remote contexts.

Furthermore, the study findings show that motivational theories could be meaningfully used to extend the understanding of the grounds leading teachers to opt for voice over exiting a remote school. This is because a close look at the findings from conditions such as empowering, attentiveness, cooperative leadership, friendliness outside of the school environment, and a

\footnotetext{
${ }^{5}$ Investment is used in this study context to mean teachers' perceived valuable contribution to the school/profession/community. It may include time spent, energy devoted, social and human capital accumulated over time (some of which may be specific to the teaching profession), physical establishments for generating incomes like businesses established within 'educational supportive arrangements' such as reduced or no tax deduction agreements in schools and/or educational settings,
} 
supportive and peacefully working environment broadly suggest that the decision to voice or exit is built on a variety of factors. They include, for instance, the need for achievement, recognition, possibility of influencing policies and reforms in their schools and work. These are part of the 'motivators' in Herzberg's theory, improvement in co-workers' support and better school head exchange relations - which are part of 'hygiene factors' in Herzberg's theory (Herzberg, Mausner \& Snyderman, 1959; Herzberg, 1966; Ramlall, 2004), fair treatment of teachers and the distribution and sharing of school level benefits/opportunities/resources; also are part of equity theory (Pinder, 1984; Ramlall, 2004; Robbins, 1993). Moreover, the findings stress the need for decent housing and basic social services (notably in habitability conditions), the need for safety, e.g., from being attacked by wild animals, robbery, diseases, the need for love, friendship, affection, belongingness, the need to be respected and valued (by students and the community). All these could be meaningfully explained within Maslow's basic needs of physiological safety, love, esteem, and self-actualization (Maslow, 1943; Ramlall, 2004). Equally notable from the findings is that the voicing conditions are defined within aspects which enhance teachers' autonomy in their work, better performance and knowledge of results and feedback; part of the job characteristic model (Hackman \& Oldham, 1980; Pinder, 1984).

It could, therefore, be argued that teachers define 'voicing over exiting conditions' by focusing on aspects which enhance their motivation and satisfaction in the work and living environment, partly because they reinforce qualities of their lives and well-being (Diener, 1995; Hagerty, 1999). Implicitly, and in logical agreement with Steers and Porter (1983), it could be suggested from the findings that school managements need to create a climate conducive to realizing 'those basic needs', thereby reducing teachers' frustration, and hence enhancing voicing and retention. Moreover, the findings pose a challenge to the school head to design and develop comprehensive reward systems that are more in line with 'justice practices'.

A further critical reflection on the findings, particularly of the influential voicing conditions of 'life as a challenge mindset' and 'patriotism and professional commitment', triggers thoughts about the critical question: 'Who actually goes into the teaching career in Tanzania'? This is because the findings, particularly with regard to these two conditions depict teachers as having difficulty in adapting their mindset and [in mitigating a] low attachment to the profession. Such findings suggest that 'career choice' perspectives could be useful in offering more explanatory insights into why such a situation arises. In this context, two career choice theories, i.e. social 
cognitive career theory (SCCT) and work adjustment theories are used to strengthen this discussion.

Within social cognitive career theory (SCCT), for instance, it could be argued that as many teachers in Tanzania as joined teaching as their 'last resort ${ }^{6}$ ', lack internal/intrinsic motivation for it, which strongly underlines the need for more tangible external rewards or reinforcements in order to retain them (Lent, 2005). Moreover, since they operate in a context not in their interest within a poor working environment, this means that the energy to perform better is low and the perceived difficulty of the work becomes high and probably more stressful. Such perceived failure to achieve a 'personal performance accomplishment' may deprive teachers of their self-efficacy. It may instead reinforce a low attachment to career, making voice a less attractive option, especially in remote area contexts with many problems. The situation is made worse by teachers' perceived low returns -'low outcome expectations - [of] external rewards'- (e.g., low salary and respect) from the profession, which might make them likely to devote less effort to their tasks. According to the SCCT interest model, individuals mostly develop an interest in activities that they feel efficacious and associate with positive outcomes (Lent, 2005). The findings regarding these two conditions, viewed from a career choice perspective, suggest the absence of a mutual balance between most teachers and their work environments, i.e., schools and the profession (Dawis, 2005; Lent, 2005), which make their adjustment and attachment difficult. This is validated by the work adjustment theory (TWA) that teachers' failure to satisfy their psychological and/or physical needs through their schools and the teaching profession explains the incongruence between the teachers on the one hand, and schools/teaching profession, on the other. In such circumstances, teachers are likely to act with inflexibility, (when they are intolerant and easily dissatisfied with the environmental conditions) and a lack of perseverance (unable to wait to try to adjust within the prevailing contextual condition) (Dawis, 2002; 2005), making voicing a costly (less attractive) option and retention altogether difficult.

\footnotetext{
${ }^{6}$ Some exceptions persists in Tanzania where teachers join the teaching profession because of their love of and personal interest in the profession, as well as the influence from significant others, including parents, friends and other people who matter to them (cf. Sumra, 2004; Mkumbo, 2012).However, to a great extent, evidence shows that most of the teachers in Tanzania are pulled into the teaching career by extrinsic 'circumstantial' forces. Although both intrinsic and extrinsic motivational aspects positively influence employees' retention (Ramlall, 2004; Watt \& Paul, 2007; Samuel \& Crispen, 2009), yet, in contexts like remote schools in Tanzania, where plenty of de-motivators persist, retaining teachers of high calibres is a challenge of gigantic proportions.
} 


\section{Implications for Teachers' retention in remote schools}

The findings generally suggest that teachers' decision to voice over exit in remote schools is grounded on diverse factors including those emanating from school managerial practices, collegial support and from factors outside school environments. It is also based on the [socio-psychological] make-up of individual teachers, the economy [of their remote location], and the grounds for the choice of career and life quality enhancement. This has strong implications in terms of thinking and providing relevant voicing arenas.

Notably, since voicing is primarily about participatory management (Stueart \& Morgan, 2007), if well understood and used, it could help as Armstrong (2006) noted, to articulate individual dissatisfaction with management or the organization. It could enhance the perceived sense of collective organizational management. It could strongly help in making employee contributions to management decision-making, particularly regarding work organization, quality, and productivity successful. Moreover, it could demonstrate the mutuality of the employeremployee relationship.

Generally, the findings imply that in order to meaningfully retain remote teachers in the Tanzanian context through voicing, several requirements must be met: -

- Empower teachers to influence changes and reforms that matter to them,

- Increase teachers sense of investment in the schools they are posted to and in the profession (social and financial capital). This includes checking the entry regulations into the teaching profession - 'who really goes into the teaching and with what level of struggle',

- Improve school level relationships including just practices from leaders and management, as well as positive co-worker exchanges,

- Facilitate training teachers to become patriotic to the nation and to be committed to the teaching profession,

- Work to improve cooperation and understanding between schools and their surrounding communities. 


\section{Conclusion and Recommendations}

This paper has discussed the conditions perceived conducive by teachers in an ideal remote school in Tanzania that could make them resort to voicing over exiting. Seven influential and two non-influential conditions are identified and discussed. Close analysis implies that the conditions are grounded in teachers' beliefs that changes are possible and that they could positively contribute to those changes; on a feeling of an investment level within the school and the profession, that is the social and other capital dimensions, entry and exit costs; as well as on the plausibility of alternative jobs existing in the labour market. Above all, these conditions show the importance of addressing teachers' sources of low retention in Tanzanian remote schools, as teachers are likely to leave remote dissatisfying situations whether or not they are native to that remote local area even if they have no feasible alternative employment.

The findings have shed light on important areas of concentration towards influencing voicing over exiting among remote secondary school teachers in Tanzania. However, these conditions need to be improved before they can be used. This is partly because the definitions of those conditions are grounded on various issues which lead to difficulties in operationalization. Moreover, these conditions can be explained from a number of theoretical perspectives, including organizational support/perceived organizational support, leader-member exchanges, co-worker exchanges, the exit, voice, and loyalty framework as well as motivational and career choices. Equally, responses seem unstable from the viewpoint of their differences across those in agreement, disagreements, and uncertainty, whereby a slight change within schools or in teachers' labour market may lead to significantly higher or lower changes in voicing-exiting options. Indisputably, the effective implementation of these conditions requires a broad knowledge of these aspects.

In the light of the above discussion, significant implications are drawn for school-level leadership and management practices in Tanzanian remote schools, particularly in Dodoma region. It is recommended that school managements should strengthen teachers' involvement through power decentralization, banking more on collegial management and leadership practices and avoiding dictatorial leadership; they should create arenas for reflective dialogue and open discussion, as well as strengthening support in schools; and work towards improving teachers' commitment (especially through enhancing their perceived investment) to the profession and to 
the schools they are working in. By doing that, teachers' ties with their schools can be increased and perceptions that changes are possible will be realized.

\section{References}

Agyeman, C. M., \& Ponniah, V. M. (2014). Employee demographic characteristics and their effects on turnover and retention in MSMEs. International Journal of Recent Advances in Organizational Behaviour and Decision Sciences (IJRAOB), 1 (1), 12-29.

Ahuja, M. K., Chudoba, K. M., Kacmar, C. J., McKnight, D. H., \& George, J. F. (2007). IT road warrior: Balancing work-family conflict, job autonomy and work overload to mitigate turnover intentions. MIS Quarterly, 31(1), 1-17.

Akiba, M., Gerald, K. L., \& Jay, P. S. (2007). Teacher quality, opportunity gap, and national achievement in 46 countries. Educational Researcher, 36(7), 369-387.

Akyeampong, K., \& Lewin, K. (2002). From student teachers to newly qualified teachers in Ghana: insights into becoming a teacher. International Journal of Educational Development, 22(3-4), 339-352.

Armstrong, M. (2014). A handbook of human resources management practice (13 ${ }^{\text {th }}$ ed.). London, England: Kogan Page Publishers.

Armstrong, M. (2006). Handbook of human resource management practice $\left(10^{\text {th }}\right.$ ed.). London, England: Kogan Page Publishers.

Ballinger, G. A., David, W., \& Schoorman, F. D. (2010). Leader-member exchange and turnover before and after succession events. Journal of Organizational Behaviour and Human Decision Processes, 113(1), 25-36.

Basford, T. E., \& Offermann, L. R. (2012). Beyond leadership: The impact of co-worker relationships on employee motivation and intent to stay. Journal of Management and Organization, 18(6), 807-817.

Bennell, P., \& Akyaempong, K. (2007). Teacher motivation in Sub-Saharan Africa and South Asia, Educational Papers, Issue 71. London, England: Department for International Development. 
Bennell, P., \& Mukyanuzi, F. (2005). Is there a teacher motivation crisis in Tanzania? Dar es Salaam, Tanzania. HR Consult.

Bennell, P., Hyde, K. \& Swainson, N. (2002). The impact of HIV/AIDS on the education sector in sub-Saharan Africa: The main findings and recommendations of a three-country study. Brighton, England: Centre for International Education, University Sussex Institute of Education.

Bernard, A. (2002). Lessons and implications for girls' education activities: A synthesis from evaluations. New York, NY: UNICEF.

Blau, P. M. (1964). Exchange and power in social life. New York, NY: Wiley.

Borman, G. D., \& Maritza, N. D. (2008). Teacher attrition and retention: A meta-analytic and narrative review of the research. Review of Educational Research, 78(3), 367-409.

Boxall, P., \& Purcell, J. (2003). Strategy and human resource management ( $3^{\text {rd }}$ ed.). London, England: Palgrave Macmillan.

Boyd, D., Pam, G., Marsha, I., Hamilton, L., Susanna, L., \& James, W. (2011). The influence of school administrators on teacher retention decisions. Journal of American Educational Research, 48(2), 303-333.

Braun, V., \& Clarke, V. (2006). Using thematic analysis in psychology. Qualitative Research in Psychology, 3(2), 77-101.

Brock-Utne, B. (2007). Language of instruction and student performance: New insights from research in Tanzania and South Africa. International Review of Education, 53(5-6), 509530.

Caracelli, V. J., \& Jenniffer, C. G. (1993). Data analysis strategies for mixed-method evaluation designs. Journal of Educational Evaluation and Policy Analysis, 15(2), 195-207.

Chenelo, A. J. (2011). Teachers' recruitment and retention in Tanzanian private secondary schools: A case of Mbeya Region. Unpublished Master of Educational Management and Administration (MEMA) dissertation, University of Dar es Salaam, Dar es Salaam, Tanzania. 
Chiaburu, D. S., \& Harrison, D. A. (2008). Do peers make the place? Conceptual synthesis and meta-analysis of co-worker effects on perceptions, attitudes, OCBs, and performance. Journal of Applied Psychology, 93(5), 1082-1103.

Chou, R. J., \& Robert, S. A. (2008). Workplace support, role overload, and job satisfaction of direct care workers in assisted living. Journal of Health and Social behaviour, 49(2), 208222.

Clay, C., \& Olitt, R. (2012). Peer power: Transforming workplace relationships (1 $1^{\text {st }}$ ed.). San Francisco, CA: Jossey-Bass.

Coleman, J. S., Campbell, E. Q., Hobson, C. J., McPartland, J., Mood, A. M., Weinfeld, F. D., \& York, R. L. (1966). Equality of educational opportunity. Washington, DC: USA: Government Printing Press.

Creswell, J. W. (2003). Research design: qualitative, quantitative and mixed methods approaches, ( $2^{\text {nd }}$ ed.). Thousand Oaks, CA: SAGE Publications.

Creswell, J. W. (2009). Research design: qualitative, quantitative, and mixed methods approaches, ( $3^{\text {rd }}$ ed.). Los Angeles, CA: SAGE Publications.

Dadey, A., \& Harber, C. (1991). Training and professional support for headship in Africa. London, England: Commonwealth Secretariat, Education Programme.

Dawis, R. V. (2002). Person-environment-correspondence theory. In D. Brown \& Associates (Eds.), Career choice and development ( $4^{\text {th }}$ ed., pp. 427-464). San Francisco, CA: JosseyBass.

Dawis, R. V. (2005). The Minnesota theory of work adjustment. In S. D. Brown \& R. T. Lent (Eds.), Career development and counselling: Putting theory and research to work (pp. 323). Hoboken, NJ: Wiley.

DeConinck, J. B. (2009). The effect of leader-member exchange on turnover among retail buyers. Journal of Business Research, 62(11), 1081-1086.

De Grauwe, A. (2001). School supervision in four African countries: Challenges and reforms. Paris, France: UNESCO/IIEP. 
Diener, E. (1995). A value based index for measuring national quality of life. Journal of Social Indicators Research, 36(2), 107-127.

Dowding, K., John, P., Mergoupis, T., \& van Vugt, M. (2000). Exit, voice and loyalty: Analytic and empirical developments. European Journal of Political Research, 37(4), 469-495.

Driscoll, D. L., Appiah-Yeboah, A., Salib, P., \& Rupert, D. J. (2007). Merging qualitative and quantitative data in mixed methods research: How to and why not. Ecological and Environmental Anthropology, 3(1), 18-28.

Eisenberger, R., Huntington, R., Hutchison, S., \& Sowa, D. (1986). Perceived organizational support. Journal of Applied Psychology, 71(3), 500-507.

Epitropaki, O., \& Martin, R. (1999). The impact of relational demography on the quality of leadermember exchanges and employees' work attitudes and well-being. Journal of Occupational and Organizational Psychology, 72(2), 237-240.

Epitropaki, O., \& Martin, R. (2005). From ideal to real: A longitudinal study of the role of implicit leadership theories on leader-member exchanges and employee outcomes. Journal of Applied Psychology, 90(4), 659-676.

Erdogan, B., \& Jeanne, E. (2007). Support from the top: Supervisors' perceived organizational support as a moderator of leader-member exchange to satisfaction and performance relationships. Journal of Applied Psychology, 92(2), 321-330.

Gaynor, C. (1998). Decentralization of education: Teacher management. Washington DC, USA: World Bank.

Gerstner, C. R., \& Day, D. V. (1997). Meta-analytic review of leader- member exchange theory: Correlates and construct issues. Journal of Applied Psychology, 82(6), 827-844.

Gottelmann-Duret, G., \& Hogan, J. (1998). The utilization, deployment and management of teachers in Botswana, Malawi, South Africa and Uganda. Paris, France: UNESCO.

Griffeth, R. W., Hom, P. W., \& Gaertner, S. (2000). A meta-analysis of antecedents and correlates of employee turnover: Update, moderator tests, and research implications for the next millennium. Journal of Management, 26(3), 463-488. 
Goldhaber, D., \& Anthony, E. (2004). Can teacher quality be effectively assessed? Washington, D.C.: Centre for Reinventing Public Education, Evans School of Public Affairs, University of Washington.

Gorden, W. L. (1988). Range of employee voice. The Journal of Employee Responsibilities and Rights, 1, 283-299.

Guarino, C., Santibañez, L., Daley, G., \& Brewer, D. (2004). A review of the research literature on teacher recruitment and retention. Santa Monica, CA: RAND Corporation.

Hackman, J. R., \& Oldham, G. R. (1980). Work redesign. Reading, MA: Addison-Wesley.

Hagerty, M. R. (1999). Testing Maslow’s hierarchy of needs: National quality-of-life across time. An International and Interdisciplinary Journal for Quality of Life Measurement, 46(3), 249-271.

Herzberg, F., Mausner, B., \& Snyderman, B. (1959). The motivation to work. New York, NY: Wiley.

Herzberg, F. (1966). Work and the nature of man. Cleveland, OH: World Publishing Company.

Hirschman, A. O. (1970). Exit, voice and loyalty: Responses to decline in firms, organizations, and states. Cambridge, England: Harvard University Press.

Ingersoll, R. (2001). Teacher turnover and teacher shortages: An organizational analysis. American Educational Research Journal, 38(3), 499-534.

International Task Force on Teachers for EFA (ITFTEFA, 2010). Teacher attrition in Sub-Saharan Africa: The neglected dimension of the teacher supply challenge. Paris, France: UNESCO.

January, M. (2010). Factors influencing retention of teachers in public secondary schools in Tanzania: The case of selected public secondary schools in Ilala District in Dar es Salaam Region. Unpublished Master of Educational Management and Administration (MEMA) dissertation, University of Dar es Salaam, Dar es Salaam, Tanzania.

Kavanaugh, J., Jo, A. D., \& Juliana, L. (2006). The relationship between job satisfaction and demographic variables for healthcare professionals. Management Research News, 29(6), $304-325$. 
Johnson, S. M., \& Birkeland, S. E. (2003). Pursuing a "sense of success": New teachers explain their career decisions. Journal of American Educational Research, 40(3), 581-617.

Johnson, B., \& Larry, C. (2012). Educational research: Qualitative, quantitative, and mixed approaches $\left(4^{\text {th }}\right.$ ed.). Thousand Oaks, CA: SAGE Publications.

Kadzamira, C. E. (2006). Teacher motivation and incentives in Malawi. Research Fellow Centre for Educational Research and Training, University of Malawi.

Kelly, M. J. (2000). Planning for education in the context of HIV/AIDS. Paris, France: UNESCO/IIEP.

Kirby, S. N., \& Grissmer, D. W. (1993). Teacher attrition: Theory, evidence, and suggested policy options. Santa Monica, CA: Rand.

Kucera, K. M., \& Stauffer, M. (2003). Attracting, developing and retaining effective teachers: OECD Swiss country background report. Geneva, Switzerland: Swiss Council for Educational Research.

Leah, M. O-H., \& Colin, R. B. (2013). Contextualizing LMX within the workgroup: The effects of LMX and justice on relationship quality and resource sharing among peers. The Leadership Quarterly, 24(6), 935-951.

Lent, R. W. (2005). A social cognitive view of career development and counselling. In S. D. Brown \& R. T. Lent (Eds.), Career development and counselling: Putting theory and research to work (pp. 101-127). Hoboken, NJ: Wiley.

Leung, S. A. (2008). The big five theories. In J. A. Athanasou \& V. E. Raoul (Eds.), International handbook of career guidance. New York, NY: Springer Science and Business Media.

Levinson, H. (1965). Reciprocation: The relationship between man and organization. Administrative Science Quarterly, 9(4), 370-390.

Lewin, K. (2008). Strategies for sustainable financing of secondary education in sub-Saharan Africa. Working Paper Number 136. Washington, DC, USA: The World Bank.

Liden, R. C., Sparrowe, R. T., \& Wayne, S. J. (1997). Leader-member exchange theory: The past and potential for the future. Research in Personnel and Human Resources Management, 15(1), 47-119. 
Little, J. W. (1990). The persistence of privacy: Autonomy and initiative in teachers' professional relations. Teachers College Record, 91(4), 509-536.

Lowe, J. M. (2006). Rural education: Attracting and retaining teachers in small schools. The Rural Educator, 27(2), 28- 32.

Luchak, A. A. (2003). What kind of voice do loyal employees use? British Journal of Industrial Relations, 41(1), 115-134.

Mbiling'i, G. (2011). Effectiveness of retention strategies of public secondary school teachers in Tanzania. A case of Kinondoni municipal council. Unpublished Master of Business Administration (MBA), University of Dar es Salaam, Dar es Salaam, Tanzania.

McCabe, D. M., \& David, L. (1992). Employee voice: A human resource management perspective. California Management Review, 34(3), 112-123.

Millward, N., Alex, B., \& John, F. (2000). All change at work. London, England: Routledge.

Mkumbo, K. A. K. (2012). Teachers' commitment to, and experiences of, the teaching profession in Tanzania: Findings of focus group research. International Education Studies, 5(3), 222 $-227$.

Moon, B. (2007). Research analysis: Attracting, developing and retaining effective teachers: A global overview of current policies and practices. Geneva, Switzerland: ILO/UNESCO.

Mulkeen, A. (2010). Teachers in Anglophone Africa. Issues in teacher supply, training, and management. Washington, DC, USA: The World Bank.

Mulkeen, A., David, W. C., Joan, G. D., \& Elizabeth, L. (2007). Recruiting, retaining, and retraining secondary and principals in sub-Saharan Africa. Washington, DC, USA: The World Bank.

Mulkeen, A., \& Chen, D. (2008). Teachers for rural schools: Experiences in Lesotho, Malawi, Mozambique, Tanzania and Uganda. Washington: Word Bank.

National Commission on Teaching and America's Future. (2003). No dream denied: A pledge to America's children: Summary report. Washington, DC, USA: National Commission on Teaching and America's Future. 
Ntim, S. (2013). Exploring the mismatch between teacher demand-supply in Sub-Sahara Africa: Ghana as case study. Mediterranean Journal of Social Science, 4(1), 273-284.

Onyango, E. (2013, December $\left.15^{\text {th }}\right)$. Pay teachers arrears promptly, House committee urges government. The Guardian. Dar es Salaam, Tanzania.

Peter, F. (2012, October $\left.5^{\text {th }}\right)$. Tanzania Teachers' Union (TTU) boycotts World Teachers Day. The Guardian. Dar es Salaam, Tanzania.

Pinder, C. (1984). Work motivation: Theory, issues, and applications. Glenview, IL: Scott, Foresman and Company.

Pitsoe, J. V. (2013). Teacher attrition in South Africa: Trends, challenges and prospects. Journal of Social Science, 36(3), 309-318.

Pitsoe, V. J., \& Pertunia, R. M. (2012). Teacher attrition catastrophe in Sub-Saharan Africa: A hurdle in the achievement of UPE, EFA policy goals and MDGs. Science Journal of Sociology and Anthropology, 2012, 1-7. doi: 10.7237/sjsa/215

Ramlall, S. (2004). A review of employee motivation theories and their implications for employee retention within organizations. Journal of American Academy of Business, 5(1/2), 52-63.

Rhoades, L., \& Eisenberger, R. (2002). Perceived organizational support: A review of the literature. Journal of Applied Psychology, 87(4), 698-714.

Riley, K. (1999). Effective schools and teachers. Washington, DC, USA: The World Bank.

Rivkin, S. G., Hanushek, E. A., \& Kain, J. F. (2005). Teachers, schools and academic achievement. Econometrica, 73(2), 417-458.

Robbins, S. (1993). Organizational Behaviour (6 $6^{\text {th }}$ ed.). Englewood Cliffs, NJ: Prentice-Hall.

Rockoff, J. (2003). The impact of individual teachers on student achievement: Evidence from panel data. Cambridge, MA: National Bureau of Economic Research.

Ross, A., \& Hutchings, M. (2003). Attracting, developing and retaining effective teachers in the United Kingdom of Great Britain and Northern Ireland: OECD Country Background Report. London, England: London Metropolitan University, Institute for Policy Studies in Education, London. 
Rowan, B., Correnti, R., \& Miller, R. J. (2002). What large-scale, survey research tells us about teacher effects on student achievement: Insights from the prospectus study of elementary schools. Teachers' College Record, 104(8), 1525-1567.

Rowe, K. (2003). The importance of teacher quality as a key determinant of students' experiences and outcomes of schooling. A paper presented in Building Teacher Quality conference: What does the research tell us? http://research.acer.edu.au/research_conference_2003/3

Rusbult, C., Johnson, D. J., \& Morrow, G. D. (1986). Determinants and consequences of exit, voice, loyalty and neglect: Responses to dissatisfaction in adult romantic involvements. Journal of Human Relations, 39, 45-63.

Rweyemamu, A. (2014 October $\left.18^{\text {th }}\right)$. Teachers up in arms with government over deductions. The Guardian. Dar es Salaam, Tanzania.

Rweyemamu, A. (2013 July $2^{\text {nd }}$ ). More than 50 teachers under one roof. The Guardian. Dar es Salaam, Tanzania.

Samuel, M. O., \& Crispen, C. (2009). Employee retention and turnover: Using motivational variables as a panacea. African Journal of Business Management, 3(8), 410-415.

Sanders, W. L., \& Rivers, J. C. (1996). Cumulative and residual effects of teachers on future student academic achievement. Knoxville, TN: University of Tennessee Value-Added Research and Assessment Centre.

Sanders, W. L., \& Horn, S. P. (1998). Research findings from the Tennessee Value-Added Assessment System (TVAAS) database: Implications for evaluation and research. Journal of Personnel and Evaluation in Education, 12(3), 247-256.

Schriesheim, C. A., Stephanie, C. L., \& Claudia, C. C. (1999). Leader-member exchange (LMX) research: A comprehensive review of theory, measurement, and data analytic practices. Leadership Quarterly, 10(1), 63-113.

Shen, J. (1997). Teacher retention and attrition in public schools: Evidence from SASS91. The Journal of Educational Research, 91(2), 81-88. 
Sherony, K. M., \& Green, S. G. (2002). Co-worker exchange: Relationships between co-workers, leader-member exchange, and work attitudes. Journal of Applied Psychology, 87(3), 542548.

Siegal, P. H. (2000). Using peer mentors during periods of uncertainty. The Leadership and Organizational Development Journal, 21(5), 243-253.

Spencer, D. G. (1986). Employee voice and employee retention. Journal of Academy Management, $29(3), 488-502$.

Steers, R., \& Porter, L. (1983). Motivation and work behaviour ( $3^{\text {rd }}$ ed.). New York, NY: McGrawHill.

Stockard, J., \& Michael, L. (2004). Influences on the satisfaction and retention of 1st-year teachers: The importance of effective school management. Educational Administration Quarterly, 40(5), 742-771.

Stronge, J. H., Thomas, J. W., Pamela, D. T., \& Jennifer, L. H. (2007). What is the relationship between teacher quality and student achievement? An exploratory study. Journal of Personnel Evaluation in Education, 20(3), 165-184.

Stueart, R. D., \& Moran, B. B. (2007). Library and information centre management (7 ${ }^{\text {th }}$ ed.). Westport, CT: Libraries, Unlimited.

Sumra, S. (2004). The living and working conditions of teachers in Tanzania. A research report. Dar es Salaam, Tanzania: Hakielimu Press.

Tanzania education sector analysis (TESA, 2011). Beyond primary education, the quest for balanced and efficient policy choices for human development and economic growth. Dar es Salaam, Tanzania: UNESCO.

Tashakkori, A., \& Teddlie, C. (1998). Mixed methodology: Combining qualitative and quantitative approaches. Thousand Oaks, CA: SAGE Publications.

Teddlie, C., \& Stringfield, S. (1993). Schools make a difference: lessons learned from a 10-year study of school effects. New York, NY: Teachers College Press.

Tikly, L., \& Barrett, A. (2010). Conceptualizing education quality: Towards an EdQual Framework: Presentation to CLIO seminar, Graduate School of Education, University of 
Bristol, (24 February). Retrieved April 2013 from World Wide Web: http://www.edqual.org/publications/presentations/tbclio10quality.pdf

Tikly, L., \& Barrett, A. M. (2011). Social justice, capabilities and the quality of education in low income countries. International Journal of Educational Development, 31(1), 3-14.

Towse, P., Kent, D., O-saki, F., \& Kirua, N. (2002). Non-graduate teacher recruitment and retention: Some factors affecting teacher effectiveness in Tanzania. Teaching and Teacher Education, 18(6), 637-652.

Tye, B. B., \& O’Brien, L. (2002). Why are experienced teachers leaving the profession? Phi Delta Kappan, 84(1), 24-32.

UIS (UNESCO Institute of Statistics). (2006). Teachers and educational quality: Monitoring global needs for 2015. New York, NY: UNESCO Institute of Statistics.

UNESCO (1996). Strengthening the role of teachers in a changing world: Issues, prospects and priorities. Prepared for the International Conference on Education. Bangkok, Thailand: UNESCO.

URT (2008). Teachers' development and management strategy (TDMS-2008/2013). Education sector development programme (ESDP). Dar es Salaam, Tanzania: MoEVT.

URT. (2012). Basic education statistics in Tanzania (BEST, 2008-2012). National Data. Dar es Salaam, Tanzania: MoEVT.

VSO (2002). What makes teachers tick: A policy research report on teachers' motivation in developing countries. London, England: VSO.

Watt, H. M. G., \& Paul, W. R. (2007). Motivational factors influencing teaching as a career choice: Development and validation of the FIT-choice scale. The Journal of Experimental Education, 75(3), 167-202.

Withey, M. J., \& William, H. C. (1989). Predicting exit, voice, loyalty and neglect. Administrative Science Quarterly, 34(4), 521-539.

Wilson, B., Squires, M., Widger, K., Cranley, L., \& Tourangeau, A. (2008). Job satisfaction among a multigenerational nursing workforce. Journal of Nursing Management, 16(6), 716-723. 
Woo, B. (2009). Cultural effects on work attitudes and behaviours: The case of American and Korean fitness employee. PhD Dissertation, Ohio State University, Ohio, USA.

Wright, S. P., Horn, S. P., \& Sanders, W. L. (1997). Teacher and classroom context effects on student achievement: Implication for teacher evaluation. Journal of Personnel and Evaluation in Education, 11(1), 57-67.

Yankami, W. (2014 January $7^{\text {th }}$ ). Many teachers 'fleeing' after training. The Guardian. Dar es Salaam. 